\title{
Eurhizococcus brasiliensis Wille, 1922 (Hemiptera: Margarodidae) molecular profile
}

\section{Catarina de Bortoli Munhae ${ }^{1}$, Vanderlei Geraldo Martins ${ }^{2}$, Cintia Martins ${ }^{3}$ and Odair Correa Bueno ${ }^{2}$}

\author{
${ }^{1}$ Universidade Federal do Piauí. Campus Ministro Petrônio Portella. Centro de \\ Ciências da Educação. Avenida Universitária, lado ímpar. Ininga. Teresina-PI, Brazil \\ (CEP 64049-550). Email: cmunhae@gmail.com. \\ ${ }^{2}$ Universidade Estadual Paulista. Centro de Estudos de Insetos Sociais (CEIS). \\ Avenida 24A, 1515. Rio Claro-SP, Brazil (CEP 13506-900). \\ ${ }^{3}$ Universidade Federal Delta do Parnaíba. Avenida São Sebastião, 2819. \\ Parnaíba-PI, Brazil (CEP 64202-020).
}

\begin{abstract}
Eurhizococcus brasiliensis Wille, 1922 (Hemiptera: Margarodidae), also known as ground pearl, is a root cochineal found in viticultures in several Brazilian states. It causes economic losses and is difficult to control. Given the difficulty in morphologically identifying the group, the current study aims to trace the ground pearl molecular profile by assuming that there is more than one species of this cochineal in the country. Ground pearl samples were collected in Rio Grande do Sul (Flores da Cunha and Pinto Bandeira Counties), Santa Catarina (Videira and Pinheiro Preto Counties), São Paulo (São Roque, São Miguel Arcanjo, Louveira and Indaiatuba Counties) and Pernambuco States (Petrolina County). Subsequently, the COI, ITS and 28S genes as well as the 18 RAPD primers were analyzed. The COI and ITS gene primers were not successfully amplified. The $28 \mathrm{~S}$ gene analysis formed two clades and the RAPD analysis formed three groups. The genetic and geographic distances among the herein analyzed samples were positive. Results allow inferring the existence of at least two ground pearl groups in the analyzed areas. Two hypotheses are presented in order to explain the cochineal groups' separation: (i) the founder effect action and (ii) the regional species independence. However, it is necessary to conduct complementary molecular studies using other genes as well as studies on the group taxonomy and basic biology to explain the ground pearl phylogeny.
\end{abstract}

Keywords: RAPD; Subterranean cochineal; Viticulture; 28S.
Received

April 29, 2020

Accepted

August 28, 2020

Released

August 31, 2020

Full Text Article

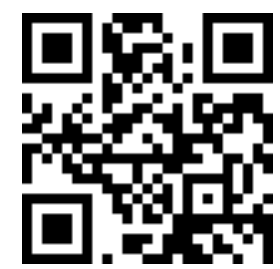

ORCID

(1) 0000-0002-5968-9717

Catarina de Bortoli Munhae

(D) 0000-0001-8481-9010

Vanderlei Geraldo

Martins

D 0000-0002-8385-9122

Cintia Martins

(D) 0000-0002-3586-6192

Odair Correa Bueno 


\section{Introduction}

Eurhizococcus brasiliensis Wille, 1922 (Hemiptera: Margarodidae) is a root cochineal also known as ground pearl. It attacks a wide variety of plants and it may lead to economic damages in grapevines. This species was first recorded in this culture in Rio Grande do Sul State, in 1921. Genus Eurhizococcus is native to South America and it has three described species: Eurhizococcus brasiliensis (Wille, 1922), Eurhizococcus brevicornis (Silvestri, 1901) and Eurhizococcus colombianus (Jakubski, 1965) (Foldi, 2005).

E. brasiliensis is found in viticultures in several Brazilian States: Rio Grande do Sul, Santa Catarina, Paraná, São Paulo, Pernambuco and Bahia (Lourenção et al., 1989; Haji et al., 2002; Haji et al., 2004). The cochineal attacks grapevine roots by inserting its stylet into the plant root system. It causes bigger damages during the first, second and third larval instars, since adults are devoid of mouthparts (Soria and Gallotti, 1986). It mainly reproduces by thelytokous parthenogenesis or, in rare occasions, sexual reproduction may occur (Hickel, 1998; Soria and Dal Conte, 2000). Controlling the cochineal is essential. However, doing it is very complex mainly because of lack of information on the species' bio-ecology, due to the difficulty of studying it, since it has subterranean habits and long life cycle (Hickel et al., 2001; Hickel, 2008).

Overall, the morphological similarities among the several cochineal groups are major problems for these species to be managed as pests (Malausa et al., 2011). Such similarities also make it difficult to study the biology and system of its cochineal. The correct species identification is directly related to its successful control. As for the ground pearl case, this control may be effective in some areas and ineffective in others. Since there is no expert able to morphologically identify this group of insects, the current study aims to analyze ground pearl by using molecular biology tools and by assuming that there is more than one cochineal species in the Brazilian grape production regions. The current study initially sought to obtain genes that might allow identifying specimens from several studied locations in order to subsequently investigate their molecular diversity.

\section{Methodology}

\section{Collection areas}

The ground pearl specimens were manually collected in the following counties: (1)

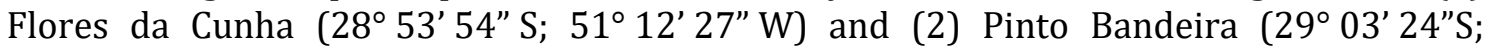

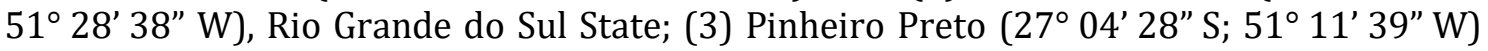
and (4) Videira $\left(27^{\circ} 03^{\prime} 67^{\prime \prime} \mathrm{S}\right.$; 51 $\left.{ }^{\circ} 06^{\prime} 10^{\prime \prime} \mathrm{W}\right)$, Santa Catarina State; (5) Indaiatuba

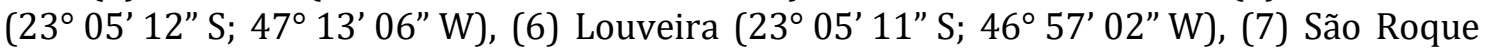

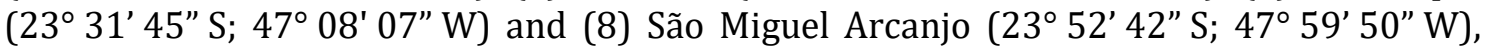

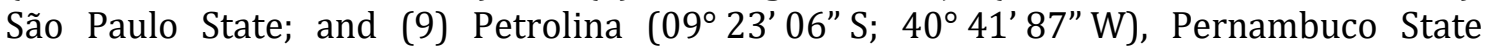
(Figure 1). All the herein collected cochineal specimens were immediately placed in $90 \%$ alcohol and kept under freezing conditions $\left(-20^{\circ} \mathrm{C}\right)$. 


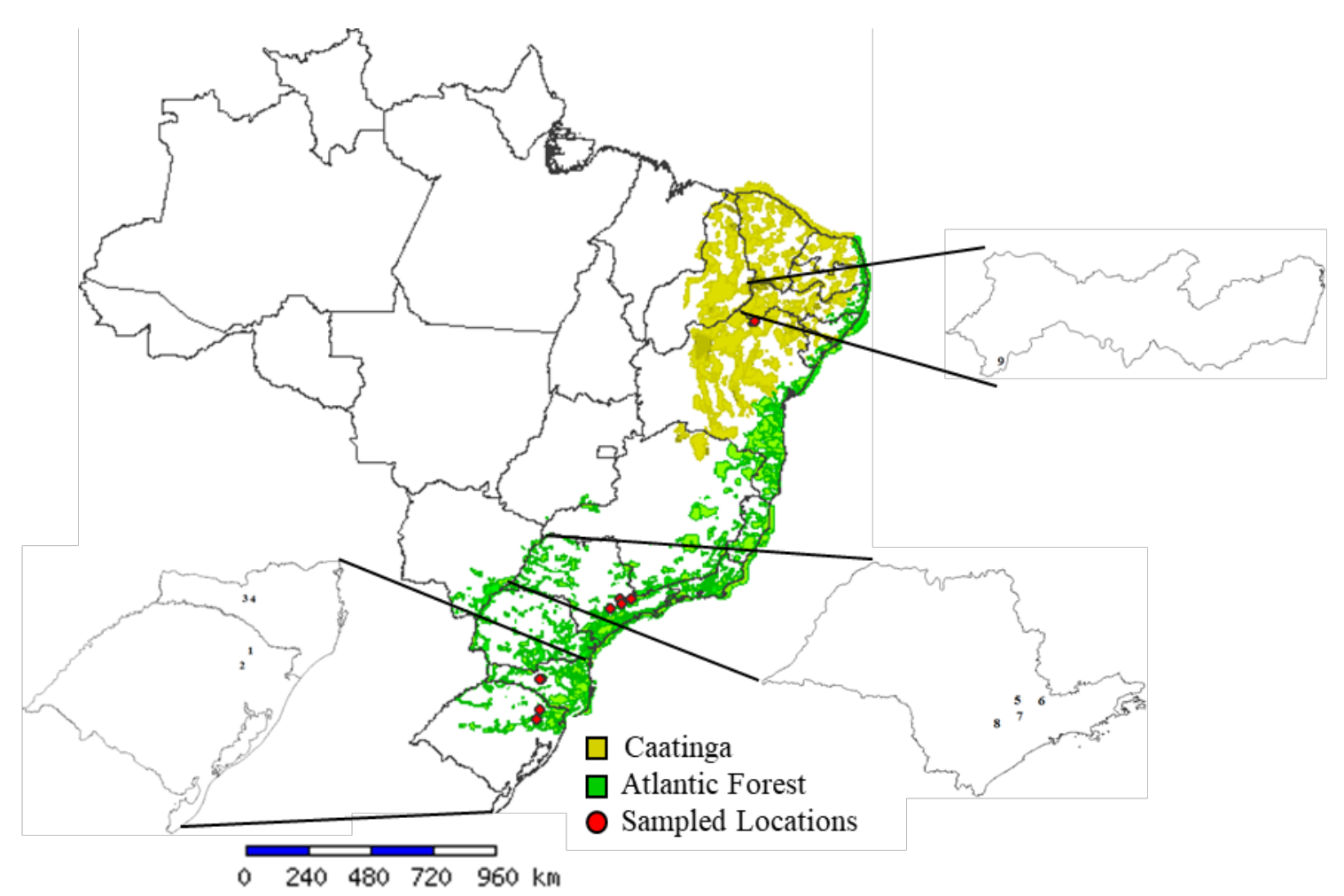

Figure 1. Brazilian map showing the locations where Eurhizococcus brasiliensis samples were collected, and their respective biomes. The numbers correspond to the sampled locations. Source: mapCria, speciesMapper modified.

\section{DNA extraction}

DNA was extracted from a single cyst-shaped cochineal individual using a small portion of its cuticle. DNA extractions were performed using the Wizard Genomic Kit (Promega ${ }^{\circledR}$ ), according to the manufacturer's recommendations.

\section{Polymerase Chain Reaction}

Using primers in COI, $\mathbf{2 8 S}$ and ITS genes amplification. Universal primers were initially used in the amplification of cytochrome oxidase (COI) fragments. Since the results were not satisfactory, new primers were prepared based on initial information; some of them were specific to ground pearl and the others were from other species from the Margarodidae family obtained from GenBank. Universal primers were also used to amplify ITS and 28S gene fragments (Table 1).

The reactions were conducted with 20-25 $\mu \mathrm{L}$ final volume using the Ready-to-go kit (Amersham Pharmacia Biotech ${ }^{\circledR}$ ), with $2 \mu \mathrm{L}$ DNA template (from 250 to $500 \mathrm{ng}$ ), $1.5 \mu \mathrm{L}$ of each primer $(0.2-0.4 \mu \mathrm{M})$; the Qiagen ${ }^{\circledR}$ kit with $12.5 \mu \mathrm{L}$ Qiagen ${ }^{\circledR}$ buffer, $0.05 \mu \mathrm{L}$ of each primer $(100 \mu \mathrm{L})$ and $2 \mu \mathrm{L}$ DNA template; and a mixture prepared from Taq Promega ${ }^{\circledR}$ containing $2.5-5 \mu \mathrm{L}$ buffer; 1.0 to $2.5 \mu \mathrm{L} \mathrm{MgCl}_{2} ; 1.0 \mu \mathrm{L}$ dNTP; $0.15-0.25 \mu \mathrm{L}$ Taq polimerase $(5 \mathrm{U} \mu \mathrm{L}) ; 1.0-1.5 \mu \mathrm{L}(1 \mathrm{mM})$ of each primer and $1 \mu \mathrm{L}$ DNA template. 
Table 1. List of primers ( $\left.5^{\prime}-3^{\prime}\right)$ and tested combinations used to amplify fragments of COI, $28 \mathrm{~S}$ and ITS genes from ground pearl samples.

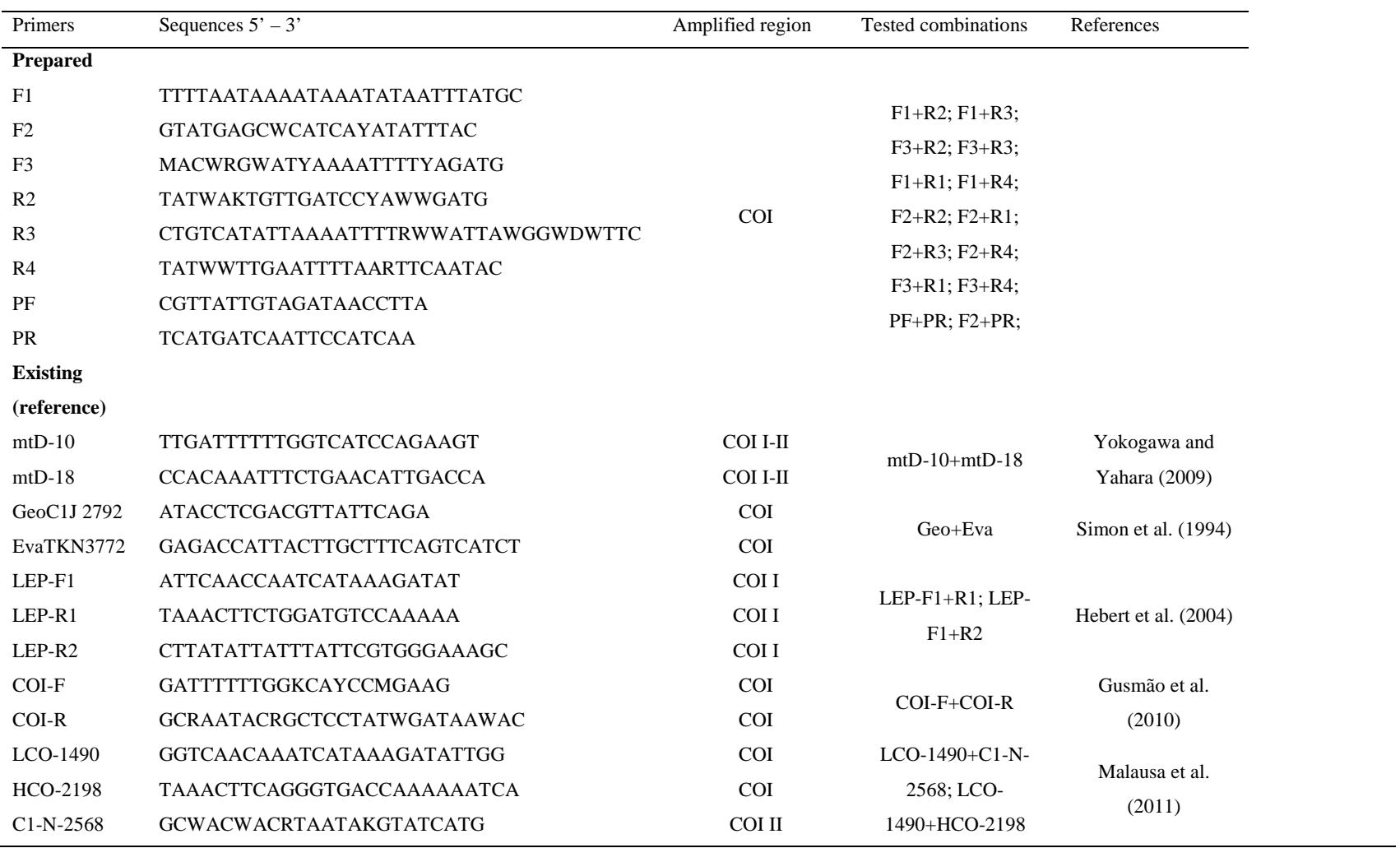

The parameters used in the thermal cycler changed according to each primer. The parameters were modified, especially in relation to denaturation time and to annealing temperature when there was no amplification. The temperatures and times used in each parameter were: initial denaturation from $94{ }^{\circ} \mathrm{C}$ to $98^{\circ} \mathrm{C}$ for $30 \mathrm{~s}-15 \mathrm{~min}$, denaturation from $94^{\circ} \mathrm{C}$ to $98^{\circ} \mathrm{C}$ for $10 \mathrm{~s}-1 \mathrm{~min}$, annealing from $40{ }^{\circ} \mathrm{C}$ to $58^{\circ} \mathrm{C}$ for $15-90 \mathrm{~s}$, elongation at $72{ }^{\circ} \mathrm{C}$ for $15-90 \mathrm{~s}$ and extension at $72{ }^{\circ} \mathrm{C}$ for $4-10 \mathrm{~min}$, repeated from 35 to 40 times. Neat and/or diluted DNA $(1: 10 ; 1: 50 ; 1: 100)$ was used. If, even then, PCR did not present the amplification product, the nested PCR resource was used, and the DNA template was the first PCR dilution product at the ratio 1:9. (Uniscience).

Amplification was confirmed on $1 \%$ agarose gel stained with $\operatorname{Red}^{\mathrm{TM}}$ Gel

DNA sequencing reactions. Once the samples were amplified, they were then purified using the "GFX"TM PCR DNA and Gel Band" kit (GE Healthcare ${ }^{\circledR}$ ). After DNA quantification in NanoDrop ${ }^{\circledR} 2000$ (Thermo Scientific), the sequencing reactions were performed using BigDye Terminator (v.3.1) (Applied Biosystem Inc.) by following the manufacturer's standard protocol. An ABI 3130 Genetic Analyzer automatic sequencer (Applied Biosystems TM) was used. The herein obtained sequences were separately analyzed using the BioEdit software (Hall, 1999). They were aligned using the Clustal application (Higgins et al., 1992) and manually edited.

The phylogeny reconstruction based on Maximum Parsimony was performed using PAUP software, version 4.0 (Swofford, 2003). Data were processed with the same weight both for gaps and for replacement. One thousand (1000) replicates were used to generate the bootstrap rates. Phylogeny reconstruction based on Bayesian inference (BI) 
was performed using MrBayes software (Huelsenbeck et al., 2001). The MrModeltest software (Nylander, 2004) was used to define the evolutionary model used in the analysis. GTR + I + G was the model chosen via AIC (Akaike Information Criterion). The MrBayes software (Huelsenbeck et al., 2001) was used with a proportion of invariable sites and the others were taken from a gamma distribution. The Markov chain was used until the standard deviation of the split frequencies were equal to or below 0.01. Ten percent $(10 \%)$ of the trees were discarded and the posterior probability values were calculated with the rest of the trees in order to summarize the parametric values and the generated trees.

The herein obtained sequences were also subjected to NETWORK 4.5 software (fluxus-engineering.com) by using the median-joining method (Bandelt et al., 1999) to establish the haplotype network.

Using RAPD primers. Since COI, 28S and ITS genes sequencing did not show satisfactory results, the RAPD analysis was performed using 40 primers (Prodimol ${ }^{\circledR}$ ). Eighteen (18) of them showed amplification in all samples and they were selected for sequence analysis (Table 2). PCR reactions were performed in $12.5 \mu \mathrm{L}$ final volume using $1 \mu \mathrm{L}$ DNA 'template' at the concentration of $12.5 \mathrm{ng}, 1 \mu \mathrm{L}$ primer $(1 \mathrm{mM}), 0.25 \mu \mathrm{L}$ Taq polymerase ( $5 \mathrm{U} / \mu \mathrm{L}$ ), $1.0 \mu \mathrm{L} \mathrm{MgCl}_{2}(25 \mathrm{mM}), 2.5 \mu \mathrm{L}$ Buffer $5 \mathrm{X}$ (Promega ${ }^{\circledR}$ ) and water. A negative control was included in the reactions - using all reagents - and without the DNA template.

Table 2. Primer code, sequence and annealing temperature of the primers used in the RAPD analysis.

\begin{tabular}{|c|c|c|}
\hline Primer code & Seq 5' - 3' & $\mathrm{Tm}$ \\
\hline OPM 03 & GGGGGATGAG & 41.6 \\
\hline OPM 04 & GGCGGTTGTC & 41.6 \\
\hline OPM 10 & TCTGGCGCAC & 41.6 \\
\hline OPM 12 & GGGACGTTGG & 41.6 \\
\hline OPM 13 & GGTGGTCAAG & 37.5 \\
\hline OPV 01 & TGACGCATGG & 37.5 \\
\hline OPV 02 & AGTCACTCCC & 37.5 \\
\hline OPV 04 & ССССТСАCGA & 41.6 \\
\hline OPV 05 & TCCGAGAGGG & 41.6 \\
\hline OPV 06 & ACGCCCAGGT & 41.6 \\
\hline OPV 07 & GAAGCCAGCC & 41.6 \\
\hline OPV 08 & GGACGGCGTT & 41.6 \\
\hline OPV 10 & GGACCTGCTG & 41.6 \\
\hline OPV 15 & CAGTGCCGGT & 41.6 \\
\hline OPV 16 & АСАССССАСА & 37.5 \\
\hline OPV 17 & ACCGGCTTGT & 37.5 \\
\hline OPV 18 & TGGTGGCGTT & 37.5 \\
\hline OPV 19 & GGGTGTGCAG & 41.6 \\
\hline
\end{tabular}

The amplifications were performed in thermocycler model 96-Well Thermal Cycler (Applied Biosystems ${ }^{\circledR}$ ) as follows: initial denaturation at $95{ }^{\circ} \mathrm{C}(4 \mathrm{~min})$, followed by 45 denaturation cycles at $92^{\circ} \mathrm{C}(15 \mathrm{~s})$, annealing (varying according to the Tm of each primer - Table 3, for $15 \mathrm{~s})$ and extension at $72{ }^{\circ} \mathrm{C}(70 \mathrm{~s})$ and final extension at $72{ }^{\circ} \mathrm{C}(6 \mathrm{~min})$ (Smith et al., 1994, modified.). The amplified product was verified by electrophoresis at $1.2 \%$, 
stained with $\mathrm{Red}^{\mathrm{TM}}$ gel (Uniscience) and subjected to $120 \mathrm{~V}, 50 \mathrm{~mA}$, for $70 \mathrm{~min}$ and then they were photographed under UV light.

Table 3. Genetic distances (upper right) of ground pearl specimens - based on RAPD analysis - and geographic distances - $\mathrm{km}$ (lower left) between the sampling locations.

\begin{tabular}{|l|l|l|l|l|l|l|l|l|l|}
\hline & PET & VID & PP & IND & LOU & SMA & SR & FC & PB \\
\hline PET & $\mathbf{0}$ & 8.83 & 8.18 & 7.74 & 8.00 & 8.30 & 8.40 & 8.30 & 7.80 \\
\hline VID & 2923.00 & $\mathbf{0}$ & 5.70 & 7.40 & 5.40 & 7.20 & 7.40 & 5.80 & 7.20 \\
\hline PP & 2935.00 & 13.70 & $\mathbf{0}$ & 6.20 & 5.90 & 7.20 & 7.20 & 6.00 & 6.40 \\
\hline IND & 2216.00 & 757.00 & 769.00 & $\mathbf{0}$ & 6.30 & 5.00 & 5.40 & 7.00 & 6.90 \\
\hline LOU & 2177.00 & 778.00 & 790.00 & 37.50 & $\mathbf{0}$ & 6.80 & 7.40 & 6.40 & 7.00 \\
\hline SMA & 2367.00 & 640.00 & 652.00 & 146.00 & 181.00 & $\mathbf{0}$ & 5.10 & 7.60 & 7.20 \\
\hline SR & 2247.00 & 748.00 & 759.00 & 79.50 & 100.00 & 120.00 & $\mathbf{0}$ & 7.60 & 7.60 \\
\hline FC & 3149.00 & 377.00 & 342.00 & 985.00 & 1006.00 & 866.00 & 975.00 & $\mathbf{0}$ & 6.70 \\
\hline PB & 3214.00 & 344.00 & 330.00 & 1051.00 & 1072.00 & 932.00 & 1039.00 & 62.60 & $\mathbf{0}$ \\
\hline
\end{tabular}

IND - Indaiatuba; FC - Flores da Cunha; LOU - Louveira; PB - Pinto Bandeira; PET - Petrolina; PP Pinheiro Preto; SMA - São Miguel Arcanjo; SR - São Roque; VID - Videira.

Different sized ladders - $50 \mathrm{pb}, 200 \mathrm{pb}$ and $1 \mathrm{~kb}$ (Promega ${ }^{\circledR}$ ) and $1 \mathrm{~kb}$ (Fermentas ${ }^{\circledR}$ ) - were used to analyze the DNA fragments amplified by RAPD technique. Thus, the size of the bands visualized in the gel may be distinguished (Figure 2). The band presence in each position in the gel was scored as 1 and its absence was scored as 0 . Data were subjected to UPGMA analysis using Euclidean distance in the NTSYS software (Applied Biostatistics, 1998).

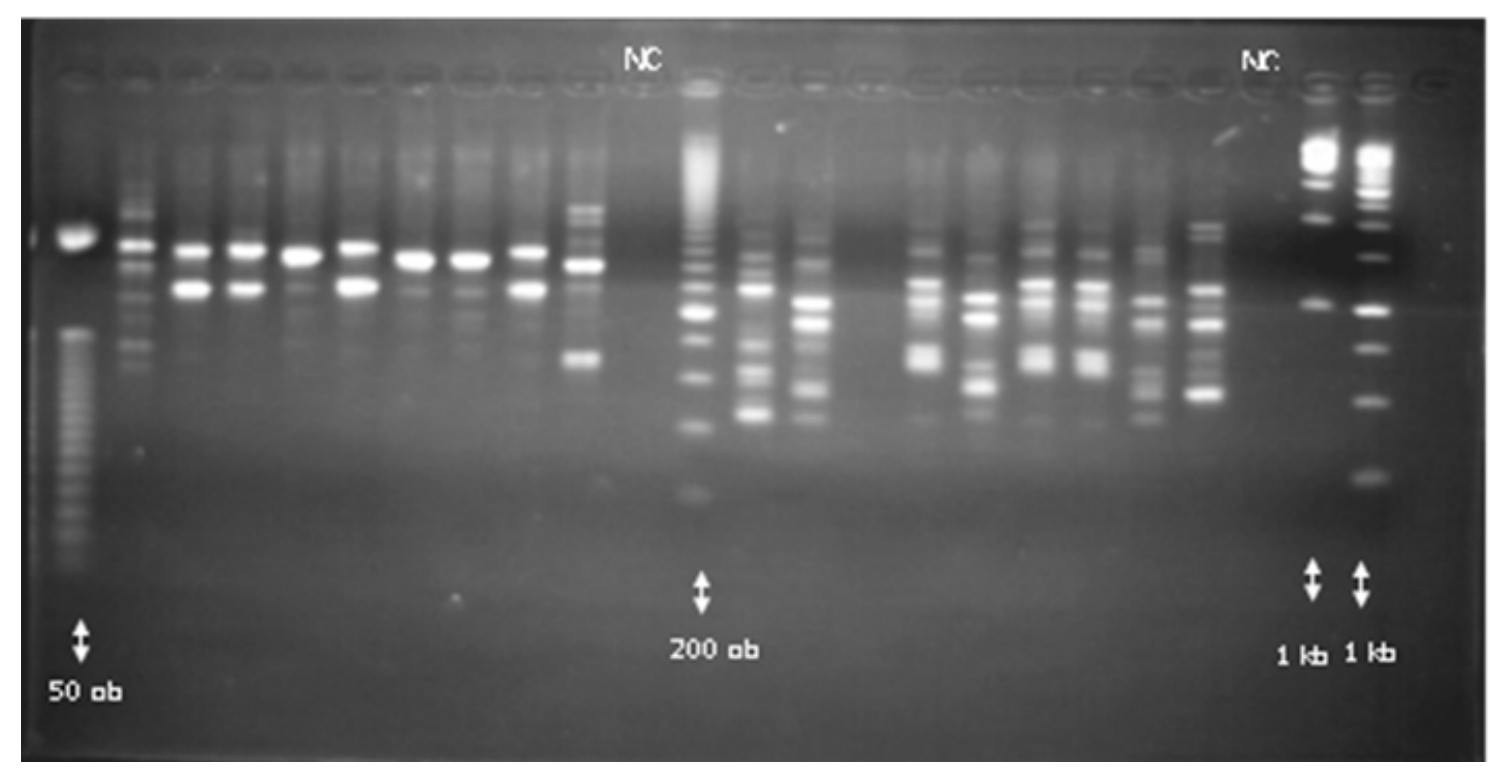

Figure 2. Fragments amplified from the OPV 10 and OPV 19 primers. The ladders are indicated by the arrow, with their respective sizes; (NC) negative control. pb - pares de bases; kb - pares de bases (x1000); NC - negative control. 
Pearson's correlation analysis between the genetic and geographic distances was performed, and the geographic distance was always considered to be the shortest route between locations.

\section{Results}

The initially used COI region primers (LEP-F1, LEP-R1, LEP-R2; mtD-10, mtD-18; LCO-1490, HCO-2198, C1-N-2568) (Table 1) were not successful in the amplification of the region of interest. Thus, the current study sought the only four sequences of species from the same Eurhizococcus brasiliensis (Margarodidae) family, which were available in the GenBank and deposited by Yokogawa and Yahara (2009) under the following records: AB439510, AB439511, AB439512, and AB439513. Sequence alignments showed little conserved regions. Several primers (F1, F2, F3, R2, R3, R4, PF, and PR) were prepared from these regions with modifications in few nucleotides (Table 1). The results are shown in Table 4.

Table 4. Results from ground pearl amplifications using all primer combinations. The approximate size of the amplified fragment, the origin of the samples and the nearest group identified in the GenBank are shown.

\begin{tabular}{|c|c|c|c|c|c|}
\hline \multirow[t]{2}{*}{ Primers } & \multicolumn{2}{|c|}{ Amplification } & \multirow[t]{2}{*}{$\begin{array}{l}\text { Place of } \\
\text { origin }\end{array}$} & \multirow{2}{*}{$\begin{array}{c}\text { Approximate size } \\
\text { of the fragment } \\
\text { (pb) }\end{array}$} & \multirow[t]{2}{*}{ GenBank } \\
\hline & Yes & No & & & \\
\hline $\mathrm{F} 1+\mathrm{R} 2$ & & $\mathrm{X}$ & & & \\
\hline $\mathrm{F} 1+\mathrm{R} 3$ & & $\mathrm{X}$ & & & \\
\hline $\mathrm{F} 3+\mathrm{R} 2$ & $\mathrm{X}$ & & $\begin{array}{l}\text { Louveira, } \\
\text { Indaiatuba, } \\
\text { Flores da } \\
\text { Cunha } \\
\end{array}$ & 410 & Scarabaeidae (COI I) \\
\hline $\mathrm{F} 3+\mathrm{R} 3$ & & $\mathrm{X}$ & & & \\
\hline $\mathrm{F} 1+\mathrm{R} 1$ & & $\mathrm{X}$ & & & \\
\hline $\mathrm{F} 1+\mathrm{R} 4$ & & $\mathrm{X}$ & & & \\
\hline $\mathrm{F} 2+\mathrm{R} 2$ & $\mathrm{X}$ & & $\begin{array}{l}\text { Louveira, } \\
\text { Indaiatuba, } \\
\text { Flores da } \\
\text { Cunha } \\
\end{array}$ & 500 & Scarabaeidae (COI I) \\
\hline $\mathrm{F} 2+\mathrm{R} 1$ & & $\mathrm{X}$ & & & \\
\hline $\mathrm{F} 2+\mathrm{R} 3$ & & $\mathrm{X}$ & & & \\
\hline $\mathrm{F} 2+\mathrm{R} 4$ & $\mathrm{X}$ & & $\begin{array}{l}\text { Louveira, } \\
\text { Indaiatuba, } \\
\text { São Roque } \\
\end{array}$ & 640 & Cerococcidae (COI I II) \\
\hline $\mathrm{F} 3+\mathrm{R} 1$ & & $\mathrm{X}$ & & & \\
\hline $\mathrm{F} 3+\mathrm{R} 4$ & & $\mathrm{X}$ & & & \\
\hline $\mathrm{PF}+\mathrm{PR}$ & & $\mathrm{X}$ & & & \\
\hline $\mathrm{F} 2+\mathrm{PR}$ & & $\mathrm{X}$ & & & \\
\hline mtD-10+mtD-18 & & $\mathrm{X}$ & & & \\
\hline C1J+Eva & & $\mathrm{X}$ & & & \\
\hline LEP-F1+R1 & $\mathrm{X}$ & & Petrolina & & \\
\hline LEPF1+R2 & & & & & \\
\hline $\begin{array}{c}\text { LCO-1490+C1-N- } \\
2568 \\
\end{array}$ & $\mathrm{X}$ & & São Roque & & No similar result \\
\hline $\begin{array}{c}\text { LCO- } 1490+\mathrm{HCO}- \\
2198 \\
\end{array}$ & & $\mathrm{X}$ & & & \\
\hline
\end{tabular}


Table 4. Continued.

\begin{tabular}{|c|c|c|c|c|c|}
\hline Primers & \multicolumn{2}{|c|}{ Amplification } & $\begin{array}{l}\text { Place of } \\
\text { origin }\end{array}$ & $\begin{array}{l}\text { Approximate size } \\
\text { of the fragment } \\
\text { (pb) }\end{array}$ & GenBank \\
\hline $\mathrm{COI}-\mathrm{F}+\mathrm{COI}-\mathrm{R}$ & $\mathrm{X}$ & & $\begin{array}{c}\text { Indaiatuba, } \\
\text { Pinto } \\
\text { Bandeira, } \\
\text { Videira, } \\
\text { Tangará, } \\
\text { Pinheiro } \\
\text { Preto, } \\
\text { Petrolina } \\
\end{array}$ & 450 & $\begin{array}{l}\text { Coccoidea/Diptera/Fungus/Aphi } \\
\text { doidea (COI I) }\end{array}$ \\
\hline 28SD2F+28SD2R & $\mathrm{X}$ & & $\begin{array}{c}\text { Indaiatuba, } \\
\text { Louveira, } \\
\text { São Roque, } \\
\text { São Miguel } \\
\text { Arcanjo, } \\
\text { Videira, } \\
\text { Pinheiro } \\
\text { Preto, Flores } \\
\text { da Cunha, } \\
\text { Pinto } \\
\text { Bandeira } \\
\end{array}$ & 400 & Pseudococcidae (28S) \\
\hline ITS2MF+MR & & $\mathrm{X}$ & & & \\
\hline ITS1-5.8s+ITS2 & $\mathrm{X}$ & & $\begin{array}{l}\text { Louveira, } \\
\text { Indaiatuba, } \\
\text { Videira }\end{array}$ & 800 & Fungus (ITS) \\
\hline
\end{tabular}

The 28S primers amplified samples corresponding to all studied locations. The other primers amplified the regions of interest to some samples, but not to the others. The comparison between the obtained sequences and those deposited in the GenBank resulted in some sequences similar to cochineals or insects as well as in other sequences very different from the group. Such fact shows the non-specificity of most of the herein used primers. Another factor that deserves to be highlighted is the fact that the gene bank compares the sequences inserted in the blast and those already deposited. Since there are not many organism sequences taxonomically close to the deposited ground pearls, the comparison between sequence similarities most often results in groups different from that of cochineal.

Thus, cytochrome oxidase (COI) gene portions were not used in the phylogenetic analysis usually done, for instance, in the studies by Shoemaker et al. (2003); Shoemaker et al. (2006) and ROSS et al. (2009).

The sequences with $28 \mathrm{~S}$ gene portions were recorded in the Genbank (with access numbers from KJ939607 to KJ939615). Although they were short, they had good quality and were used to build the phylogenetic tree. In addition, both analyses (Maximum Parsimony - MP and Bayesian Inference - BI) were almost congruent. The current study made the option for the MP tree, since it better separated the terminals, besides it presented good "bootstrap" values (Figure 3). Marchalina hellenica, which represents the Margarodidae family and is available in the gene bank, was used as outgroup in order to root the tree in the phylogenetic analysis. Only one parsimonious tree was found in the MP phylogenetic analysis. 


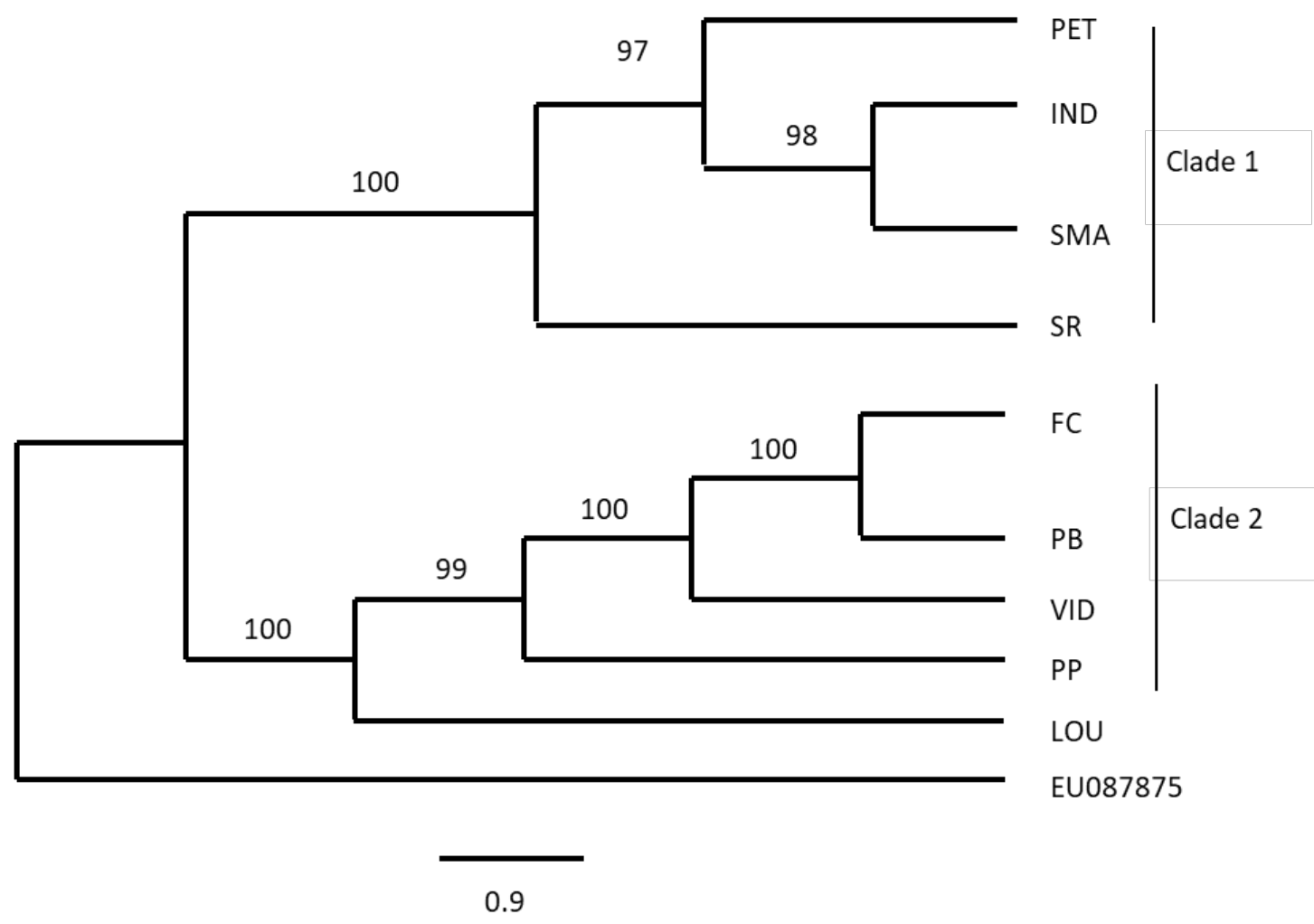

Figure 3. Maximum Parsimony (MP) tree rebuilt from the28S gene of ground pearl samples collected in the Brazilian Southern, Southeastern and Northeastern regions. "Bootstrap" values are placed above the branches. The tree was rooted using a Marchalina hellenica representative (EU087875). IND - Indaiatuba; FC - Flores da Cunha; LOU - Louveira; PB - Pinto Bandeira; PET Petrolina; PP - Pinheiro Preto; SMA - São Miguel Arcanjo; SR - São Roque; VID - Videira.

The current study was able to divide the cochineals into two main clades by using the high "bootstrap" values generated by the analysis. Clade 1: Monophyletic; it groups representatives from the Southeastern and Northeastern regions (Indaiatuba, Sao Miguel Arcanjo, São Roque and Petrolina Counties); Clade 2: Monophyletic; it groups representatives from the Southern (Flores da Cunha, Pinto Bandeira, Videira, Pinheiro Preto Counties) and from the Southeastern (Louveira) regions.

The two herein formed clades showed excellent values. Thus, it is possible to infer the existence of at least two ground pearl "species groups" in Brazil. Specimens from Rio Grande do Sul State (FC and PB) showed similarities between them, as well as the specimens from Santa Catarina State (VID and PP). However, specimens from Louveira County (São Paulo State) were more similar to the specimens from Southern Brazil (Rio Grande do Sul and Santa Catarina States) than to those found in the other Counties of São Paulo State (Indaiatuba, São Miguel Arcanjo and São Roque), which in turn, showed great similarity among them. Specimens from Petrolina County (Pernambuco State) were also closer to those from São Paulo State. Field visits allowed observing differences in the behavior of ground pearl specimens from the Southern and Southeastern regions in comparison to that of specimens from the Northeastern region.

The nine herein analyzed $28 \mathrm{~S}$ gene sequences resulted in five haplotypes (Figure 4) classified as follows: the $\mathrm{H}_{-} 1$ corresponds to Petrolina County, the H_2 corresponds to Flores da Cunha, Pinto Bandeira, Louveira and Videira Counties, the H_3 corresponds to Pinheiro Preto County, the H_4 corresponds to Indaiatuba and São Miguel 
Arcanjo Counties, and the H_5 corresponds to São Roque County. These results reinforce those obtained in the MP analysis.

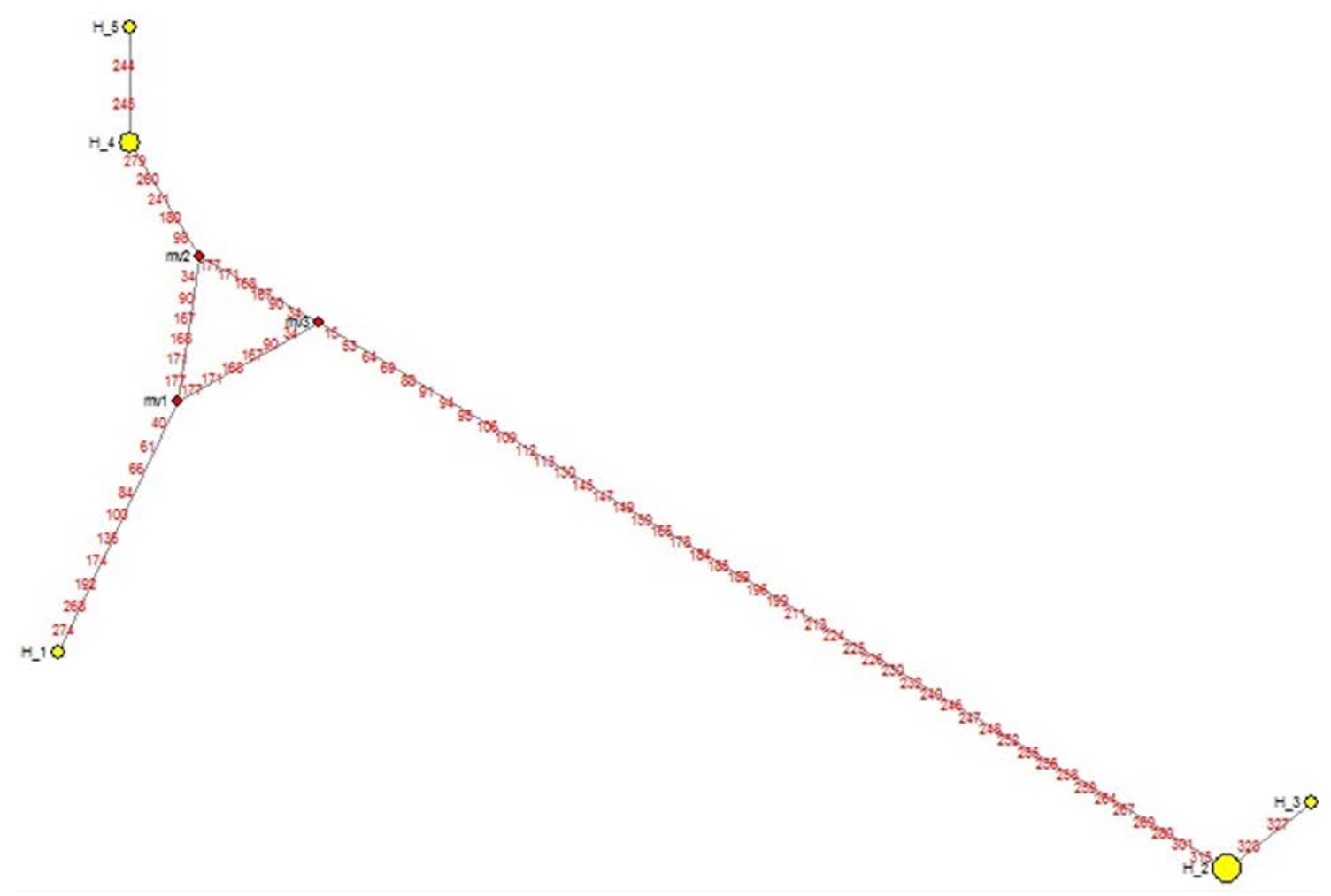

Figure 4. Haplotype network generated for ground pearl haplotypes from the $28 \mathrm{~S}$ geneof the studied locations: $\mathrm{H}_{-} 1$ corresponds to Petrolina County; $\mathrm{H} \_2$ corresponds to Flores da Cunha, Pinto Bandeira, Louveira and Videira Counties; $\mathrm{H}_{-} 3$ corresponds to Pinheiro Preto County; H_4 corresponds to Indaiatuba and São Miguel Arcanjo Counties; and H_5 corresponds to São Roque County; mv1, mv2 and mv3 indicate possible ancestors; the lines connecting the haplotypes show the divergent nucleotides among them.

The current study made the option for also using the RAPD technique, which amplifies random and small sized fragments, due to the difficulty in amplifying ground pearl genomic regions using specific primers.

These primers together generated 132 fragments, and each primer produced from 4 to 35 bands. The size of the amplified products ranged from $400 \mathrm{pb}$ to $4 \mathrm{~kb}$, and the negative control showed no amplification. Figure 4 illustrates an example of amplified fragments, in the current case, the OPV 10 and OPV 19 primers.

Dendrogram obtained from the Euclidean distance (Figure 5) revealed the existence of three groups: Group 1 consists of specimens from the Southern - Videira, Pinheiro Preto, Flores da Cunha, Pinto Bandeira Counties - and from the Southeastern Regions - Louveira County; Group 2 is formed by specimens from the Southeastern region - Indaiatuba, São Miguel Arcanjo and São Roque Counties; Group 3 consists of specimens from the Northeastern Region - Petrolina County. 


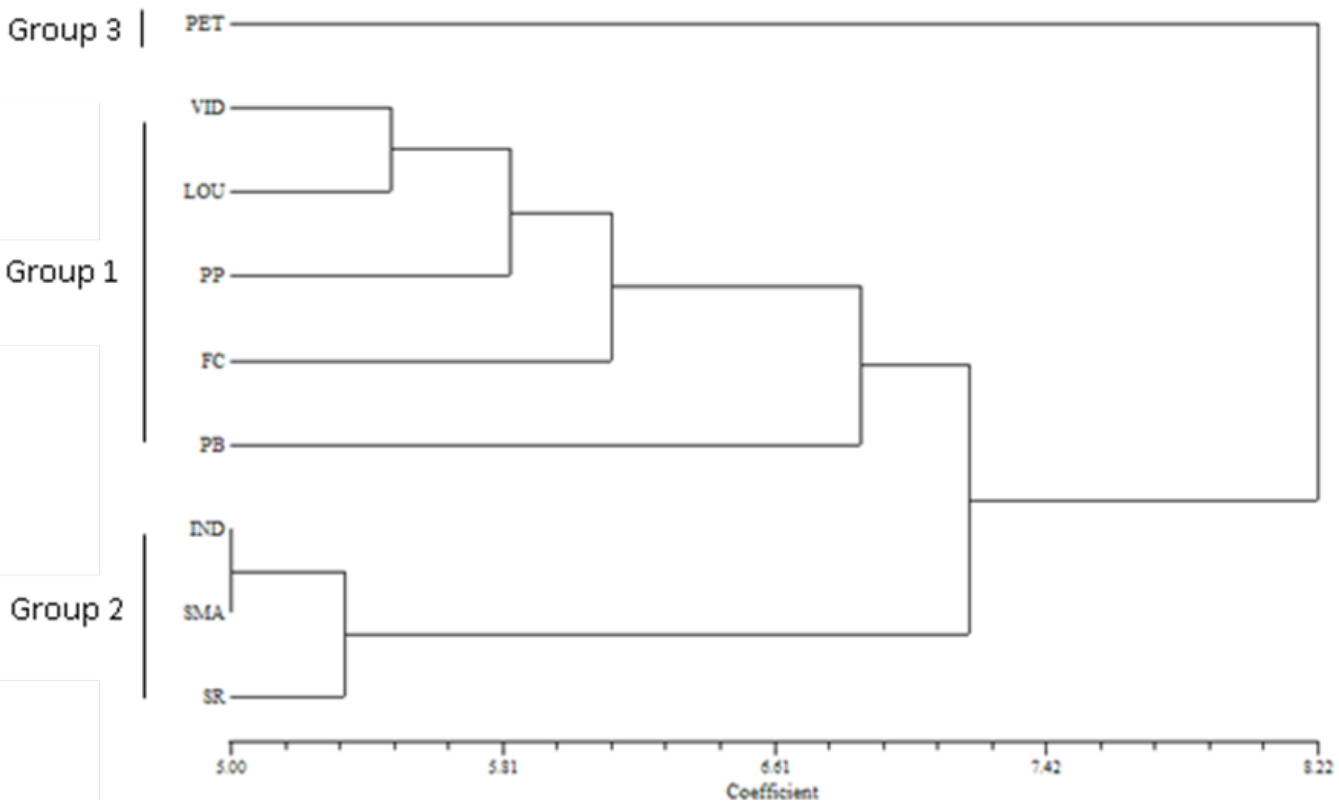

Figure 5. Dendogram obtained by the Euclidean distance UPGMA method for ground pearl occurrence location in the Brazilian Southern, Southeastern and Northeastern regions, using RAPD primers. IND - Indaiatuba; FC - Flores da Cunha; LOU - Louveira; PB - Pinto Bandeira; PET Petrolina; PP - Pinheiro Preto; SMA - São Miguel Arcanjo; SR - São Roque; VID - Videira.

The samples from Petrolina County were different from the others. Specimens from Rio Grande do Sul State (FC and PB) showed similarities among each other, as well as specimens from Santa Catarina State (VID and PP). Similarly to what happened in the MP analysis, specimens from Louveira County (São Paulo) were more similar to those from Videira County (Santa Catarina) than to those found in the other Counties of São Paulo State (Indaiatuba, São Miguel Arcanjo and São Roque), which in turn, showed great similarity among each other.

The genetic and geographic distance analysis showed that the greater the samples' distance of origin was, the greater the dissimilarity value (Pearson's coefficient, $r=0.75$ ). Table IV depicts the genetic and geographic distances between the sampling locations.

\section{Discussion}

The attempt to establish the list of Eurhizococcus brasiliensis from different Brazilian regions was not successful, despite several attempts to prepare primers from mitochondrial genes. This fact is not new among Coccoidea families, since Malausa et al. (2011) found the same problem in mealybugs (Pseudococcidae), although this group holds most molecular information about this superfamily. It suggests the difficulty in using Barcode mitochondrial genes in cochineals.

The results allow inferring the occurrence of distinct E. brasiliensis groups in Brazil. At least two "species groups" were established in the different studied regions. Such finding is corroborated by the high "bootstrap" values supporting the clades formed both by the $28 \mathrm{~S}$ gene analysis and by the congruence with the RAPD analysis.

Although there are some limitations in using the RAPD analysis method, it can be reproduced in different laboratories, since the same PCR conditions and reactant concentrations are kept. The process improvement may be achieved by increasing the 
gels' run time with low voltage to obtain better DNA fragments resolution (Smith et al., 1994). Hellsten and Sundberg (2000), McCormack and Keegan (2000), Yan et al. (2005); Chong et al. (2000); Kovacs et al. (2001); Román et al. (2003); Nagarajan et al. (2006), Premanandh et al. (2009), and Matta et al. (2013) are successful examples in differentiating ant species, groups, and colonies or even in inferring phylogenetic relations using RAPD molecular markers.

Another plausible explanation for using RAPD is the lack of molecular information about the analyzed organisms as well as the lack of satisfactory results from the analysis using universal primers. The RAPD technique allows at least separating the main groups. The herein presented results were obtained by RAPD in the separation of cochineal groups, and they were corroborated by the 28S gene Maximum Parsimony analysis.

The grouping resulting from the UPGMA analysis obtained by RAPD showed similarities to the Maximum Parsimony tree obtained from the 28S gene. In both cases, the specimens from Videira, Pinheiro Preto, Pinto Bandeira, Flores da Cunha and Louveira Counties were closer to each other than they were to the specimens from Indaiatuba, São Roque and São Miguel Arcanjo Counties. Individuals coming from Petrolina County (PE) showed different links. They formed a distinct group in the RAPD analysis and were considered to be part of Clade 1, according to the Maximum Parsimony analysis. This difference may be clarified using the $28 \mathrm{~S}$ gene fragment presenting the biggest number of base pairs.

The herein obtained results allow establishing two hypotheses (interrelated or not) about the cochineal groups' separation: hypothesis (i) the founder effect action, and hypothesis (ii) the regional species interdependence.

E. brasiliensis separation into two different groups may be related to the ground pearl origin, which is expected to come from the Brazilian Southern region, based on the facts that it was first recorded in Santa Maria County (RS) and that it has widespread occurrence in this region (Marcos Botton, personal communication). If the premise that the ground pearl is native to Southern Brazil is true, the founder effect phenomenon (i) may have occurred. However, since this fact is not enough to categorically state that the ground pearl is native to that region, one should consider the existence of different species groups and the possibility that each of them is native to the different regions separated in the analyses (ii).

Hypothesis (i) - E. brasiliensis is native to Southern Brazil and it would be transported by man to other regions through infested seedlings. According to information from Embrapa Semi-Árido researchers (Petrolina - PE), the rootstocks used in São Francisco Valley region (Northeastern region) had their origin in Embrapa Uva e Vinho (Southern Region), approximately two decades ago. The same phenomenon may have occurred in the Southeastern region. According to this hypothesis, few individuals were transported to the new location. They settled there, increased in number and colonized the nearby places. Two cochineal groups, with distinct genetic variability, came from the original population and formed two new populations, one in each region (Northeast and Southeast). These populations settled and other evolutionary events - for instance, mutations and even the natural selection or genetic drift processes - may have also genetically molded them. The fact that the specimens from Petrolina showed greater genetic similarity to specimens from São Paulo than to those from Rio Grande do Sul - in the Maximum Parsimony analysis - may due to mutations that took place after their introduction in the country. Such mutations made the specimens from these regions similar to each other. The positive correlation between genetic distance and geographic distance is also a factor that reinforces this hypothesis.

If this hypothesis is true, the difference found among the groups is likely to have occurred, since the $28 \mathrm{~S}$ gene (or other genes) evolution rate in this cochineal group is not known. Despite the short time interval in the possible ground pearl introduction in the 
Northeastern region, little is known about this organism's biology and about its interrelation with the environment. Therefore, it is not possible to infer how the environmental pressure may affect the species.

Hypothesis (ii) - E. brasiliensis is not native to Southern Brazil and the clades formed in the analyses may indicate the occurrence of different groups of this insect in different Brazilian regions. The differences among groups may be related to the different habitats they live in and to the behavior of the predominant cochineals in the regions represented by the groups or clades. The locations sampled in the Southern and Southeastern regions are located in native Atlantic Forest area, whereas the location sampled in the Northeastern region belongs to the Caatinga area. Observations made in the field along with the different biomes allowed perceiving significant cochineals' behavioral differences in both regions. Regarding the Northeastern region, it is common to see adult females coming out to the soil surface for mating in the early morning hours at the reproduction period. Flying males are also seen in this time. As for the Southern and Southeastern regions, females and males rarely appear on the soil surface.

Since E. brasiliensis is native to Brazil, the observed groups should have already occurred in native plants or even in plants grown in different locations. They should have also independently colonized each region. In order to explain this situation, the Southern region native material transported to the Northeastern region should not show cochineals in its roots, unlike the introduction of a Southern region cochineal population in Louveira County (SP).

The occurrence of sympatric speciation is not uncommon between small animal groups such as insects, mites and nematodes (Bush, 1992). This type of speciation was observed in the Rhagoletis pomonella fruit fly, which stood out when a new host was explored (Bush, 1969). It demonstrated that changing the host may lead to insect speciation. According to Futuyma (2003), the speciation process may take place very quickly and sometimes it may happen in a short period, depending on the type of organism and on its population structure.

According to Botton et al. (2008), E. brasiliensis has been found on the roots of 71 plant species. Thus, the question is: is the ground pearl species found on other host plants the same species found on grapevines? The answer to this question can only be obtained from studies that take into account the cochineals found on other hosts. The first indication that the specimens may be different on different hosts was given by Boni et al. (2003), who found genetic variability in ground pearls from different hosts in the same area. Since the grapevine (Vitis sp.) is not native to Brazil, the ground pearl should already be present on other hosts at the time of its introduction. Thus, a sympatric speciation may have happened when the ground pearl started exploring the grapevine.

The herein obtained results allow concluding that there is great genetic diversity in the E. brasiliensis populations colonizing grapevines in Brazil. The group phylogeny will only be fully explained by complementary molecular studies using other genes and by studies on the group's taxonomy and basic biology. The results revealed the group's taxonomic complexity; however, this is the first study raising hypotheses about the $E$. brasiliensis distribution in grapevines.

\section{Acknowledgement}

We are grateful to the grape producers from the studied counties in São Paulo, Santa Catarina, Rio Grande do Sul and Pernambuco States. We would also like to thank Embrapa Grape and Wine (Embrapa Uva e Vinho) and Semi-Arid Embrapa (Embrapa Semi-Árido), Santa Catarina Epagri (Agricultural Research and Rural Extension Company of Santa Catarina State) and Louveira Agriculture House (Casa de Agricultura de Louveira), Jarinu Agriculture House (Casa de Agricultura de Jarinu), Indaiatuba Rural Union 
(Sindicato Rural de Indaiatuba), Campinas Agronomic Institute (Instituto Agronômico de Campinas) and Winery Goés of São Roque (Vinícola Goés de São Roque). We also thank the National Council for Scientific and Technological Development (Conselho Nacional de Desenvolvimento Científico e Tecnológico - CNPq) for the doctoral scholarship provided to the first author.

\section{Conflicts of interest}

The authors declare that they have no conflicts of interest.

\section{References}

Applied Biostatistics Inc. NTSYS pc Version 2.02i. 1998.

Bandelt, H. J.; Foster, P.; Röhl, A. Median-joining networks for inferring intraspecific phylogenies. Molecular Biology and Evolution, v. 16, p. 37-48, 1999.

Boni, E. C.; Garrido, L. R.; Machado, C. A. E.; Revers, L. F.; Botton M.; Soria, S. J. Análise da variabilidade genética de Eurhizococcus brasiliensis em diferentes hospedeiros utilizando marcadores RAPD. Anais do X Congresso Brasileiro de Viticultura e Enologia, Bento Gonçalves, 2003.

Botton, M.; Schuck, E.; Soria, S. J.; Hickel, E. R. Manejo de pragas na cultura da videira. Bento Gonçalves: Embrapa Uva e Vinho, 2008.

Bush, G. L. Sympatric hoste hace formation and speciation in frugivorous flies of the genus Rhagoletis. Evolution, n. 23, p. 237-251, 1969.

Bush, G. L. A reaffirmation of Santa Rosalia, or why are there so many kinds of small animals. In: Edwards, D.; Lees, D. R. Evolutionary patterns and processes. New York: Academic Press, 1992. p. 229-249.

Chong, L. K.; Tan, S. G.; Yusoff, K.; Siraj, S. S. Identification and characterization of Malaysian river catfish Mystus nemurus (C and V) by RAPD and AFLP analysis. Biochemical Genetics, v. 38, p. 63-76, 2000.

Foldi, I. Ground pearls: a generic revision of the Margarodidae sensu stricto (Hemiptera: Sternorrhyncha: Coccoidea). Annual Society Entomololgy, v. 41, p. 81-125, 2005.

Futuyma, D. J. Biologia evolutiva. Ribeirão Preto: FUNPEC-RP, 2003.

Gusmão, F. A.; Harakava, R.; Campos, A. E. C. Fire-ants of the Solenopsis saevissima speciesgroup (Hymenoptera: Formicidae) nesting in parks in the City of São Paulo: Identification based on mtDNA sequences and morphological characters. Sociobiology, v. 56, p. 353362, 2010.

Haji, F. N. P.; Lima, M. P. L.; Alencar, J. A.; Barbosa, F. R.; Ferreira, R. C. F.; Mattos, M. A. A. Cochonilha pérola-da-terra: praga emergente na cultura da uva, no Submédio do Vale do São Francisco. Petrolina: Embrapa Semi-Árido, 2004. (Circular técnica, 78).

Haji, F. N. P.; Alencar, J. A.; Barbosa, F. R. Pragas. In: Lima, M.T.; Moreira, W. A. Uva de mesa fitossanidade. Brasília: Embrapa Informação Tecnológica, 2002. p. 53-68.

Hall, T. A. BioEdit: A user-friendly biological sequence alignment editor and analysis program for Windows 95/98/NT. Nucleic Acids Symposium Series, v. 41, p. 95-98, 1999.

Hebert, P. D. N.; Penton, E. H.; Burns, J. M.; Janzen, D. H.; Hallwachs, W. Ten species in one: DNA barcoding reveals cryptic species in neotropical skipper butterfly Astraptes fulgerator. PNAS, v. 101, p. 14812-14817, 2004. 
Hellsten, M. E.; Sundberg, P. Genetic variation in two sympatric European populations of Bosmina spp. (Cladocera) tested with RAPD markers. Hydrobiologia, v. 421, p. 157-164, 2000.

Hickel, E. R. Pragas da videira. In: Braga Sobrinho, R.; Cardoso, J. E.; Freire, F. C. O. Pragas de fruteiras tropicais de importância agroindustrial. Brasília: Embrapa SPI, 1998. p. 191-194.

Hickel, E. R.; Peruzzo, E. L.; Schuck, E. Pirâmide etária e distribuição espacial da pérola-daterra no Meio-Oeste Catarinense. Agropecuária Catarinense, v. 22, p. 61-68, 2008.

Hickel, E. R.; Peruzzo, E. L.; Schuck, E. Controle da pérola-da-terra, Eurhizococcus brasiliensis (Homoptera: Margarodidae), através da desinsetização. Neotropical Entomology, v. 30, p. 125-132, 2001.

Higgins, D. G.; Bleasby, A. J.; Fuchs, R. Clustal V: Improved software for multiple sequence alignment. Computer Applications in the Biosciences, v. 8, p. 189-191, 1992.

Huelsenbeck, J. P.; Ronquist, F. MRBAYES: Bayesian inference of phylogeny. Bioinformatics, v. 17, p. 754-755, 2001.

Kovacs, B.; Egedi, S.; Bartfai, R.; Orban, L. Male specific DNA markers from African catfish (Clarias gariepinus). Genetica, v. 110, p. 67-276, 2001.

Lourenção, A. L; Martins, F. P.; Alarcon, L. C. M. Ocorrência de Eurhizococcus brasiliensis (Hempel) (Homoptera: Margarodidae) em videira no Município de Louveira, Estado de São Paulo. Bragantia, v. 48, p. 205-208, 1989.

Malausa, T.; Fenis, A.; Warot, S.; Germain, J. F.; Ris, N.; Prado, E.; Botton, M.; VanlerbergheMasutti, F.; Sforza, R.; Cruaud, C.; Couloux, A.; Kreiter, P. DNA markers to disentangle complexes of cryptic taxa in mealybugs (Hemiptera: Pseudococcidae). Journal of Applied Entomology, v. 135, p. 1-14, 2011.

Matta, S. L. S. F.; Morini, M. S. C.; Hilsdorf, A. W. S. Genetic relationship among Camponotus rufipes Fabricius (Hymenoptera: Formicidae) nests by RAPD molecular markers. Acta Scientiarum, v. 35, p. 89-92, 2013.

McCormack, G. P.; Keegan, B. F. Comparative analysis of three populations of the Brittle star Amphiura filiformis (Echinodermata: Ophiuroides) with different life history strategies using RAPD markers. Marine Biotechnology, v. 2, p. 100-106, 2000.

Nagarajan, M.; Haniffa, M. A.; Gopalakrishnan, A.; Basheer, V. S.; Abdul, Muneer P. M. Genetic variability of Channa punctatus populations using randomly amplified polymorphic DNA. Aquaculture Research, v. 37, p. 1151-1155, 2006.

Nylander, J. A. A. MrModeltest v. 2. Upssala: Evolutionary Biology Centre, Upssala University, 2004.

Remanandh, J.; Priya, B.; Prabaharan, D.; Uma, L. Genetic heterogeneity of the marine cyanobacterium Leptolyngbya valderiana (Pseudanabaenaceae) evidenced by RAPD molecular markers and 16S rDNA sequence data. Journal of Plankton Research, v. 31, p. 1141-1150, 2009.

Román, B.; Alfaro, C.; Torres, A. M.; Moreno, M. T.; Satovic, Z.; Pujadas, A.; Rubiales, D. Genetic relationships among Oranbanche species as revealed by RAPD analysis. Annals of Botany, v. 91, p. 637- 642, 2003.

Ross, K. G.; Gotzek, D.; Ascunce, M. S.; Shoemaker, D. D. Species delimitation: A case study in a problematic ant taxon. Systematic Biology, v. 59, p. 1-23, 2009. 
Shoemaker, D. D.; Ahrens, M. E.; Ross, K.G. Molecular phylogeny of the fire ants of the Solenopsis saevissima species-group based on mtDNA sequences. Molecular Phylogenetics and Evolution, v. 38, p. 200-215, 2006.

Shoemaker, D. D.; Keller, G.; Ross, K. G. Effects of Wolbachia on mtDNA variation in two fire ant species. Molecular Ecology, v. 12, p. 1757-1772, 2003.

Simon, C.; Frati, F.; Beckenbach, A.; Crespi, B.; Liu, H.; Flook, P. Evolution, weighting, and phylogenetic utility of mitochondrial gene sequences and a compilation of conserved polymerase chain reaction primers. Annals of the Entomological Society of America, v. 87, p. 651-701, 1994.

Smith, J. J.; Scott-Craig, J. S.; Leadbetter, J. R.; Bush, G. L.; Roberts, D. L.; Fulbright, D. W. Characterization of Random Amplified Polymorphic DNA (RAPD) products from Xanthomonas campestris and some comments on the use of RAPD products in Phylogenetic analysis. Molecular Phylogenetics and Evolution, v. 3, p. 135-145, 1994.

Soria, S. J.; Dal Conte, A. F. Bioecologia e controle das pragas da videira no Brasil. Entomologia y Vectores, v. 7, p. 73-102, 2000.

Soria, S. J.; Gallotti, B. J. 0 margarodes da videira Eurhizococcus brasiliensis (Homoptera: Margarodidae): biologia, ecologia e controle no sul do Brasil. Bento Gonçalves: Embrapa CNPUV, 1986. (Circular Técnica, 13).

Swofford, D. L. Phylogenetic analyses using parsimony, Version 4.0b10. Washington DC: Smithsonian Institution, 2003.

Yan, J.; Liu, S.; Sun, Y.; Zhang, C.; Luo, K.; Liu, Y. RAPD and microsatellite analysis of diploid gynogens from allotetraploid hybrids of red crucian carp (Carassius auratus) $\mathrm{X}$ common carp (Cyprinus carpio). Aquaculture, v. 243, p. 49-60, 2005.

Yokogawa, T.; Yahara, T. Mitochondrial phylogeny certified PGL (Paternal Genome Loss) is of single origin and haplodiploidy sensu stricto (arrhenotoky) did not envolve from PGL in the scale insects (Hemiptera: Coccoidea). Genes and Genetic Systems, v. 84, p. 57-66, 2009.

License information: This is an open-access article distributed under the terms of the Creative Commons Attribution License, which permits unrestricted use, distribution, and reproduction in any medium, provided the original work is properly cited. 